\title{
ENTREPRENEURIAL COMPETENCY AS DETERMINANT FOR SUCCESS OF FEMALE ENTREPRENEURS IN NIGERIA
}

\author{
Mohammed Kabir")1, Hazril Izwar Ibrahim*), and Khairul Anuar Mohammad Shah") \\ *) School of Management, Universiti Sains Malaysia \\ Sasaran Road, 11800 Gelugor, Pinang Island, Malaysia
}

\begin{abstract}
This study aimed at examining the direct relationship between entrepreneurial competency and firm performance of female Entrepreneurs in Nigeria. The data were collected from respondents via the use of questionnaires, and were analysed using SPSS and Smart PLS 3.0. Evidence put forward indicated that for female Entrepreneurs in Nigeria to succeed in running their businesses effectively and efficiently, they need to equip themselves with necessary competencies. The findings revealed that strategy, opportunity and organizing competencies have positive direct relationship with firm performance.
\end{abstract}

Keywords: competency, entrepreneur, firm performance, Nigeria, PLS

\begin{abstract}
ABSTRAK
Penelitian ini bertujuan menguji hubungan langsung antara kompetensi kewirausahaan dan kinerja pengusaha wanita di Nigeria. Data dikumpulkan dari responden melalui penggunaan kuesioner, dan dianalisis dengan menggunakan SPSS dan Smart PLS 3.0. Bukti yang diajukan menunjukkan bahwa agar pengusaha wanita di Nigeria berhasil menjalankan bisnis mereka secara efektif dan efisien, mereka perlu melengkapi diri dengan kompetensi yang diperlukan. Temuan tersebut mengungkapkan bahwa strategi, peluang dan kompetensi pengorganisasian memiliki hubungan langsung yang positif dengan kinerja perusahaan.
\end{abstract}

Kata kunci: kompetensi, pengusaha, kinerja perusahaan, Nigeria, PLS

${ }^{1}$ Corresponding author:

Email: kbandshow@yahoo.com

\section{INTRODUCTION}

Globally, interest in entrepreneurship is on the rise. The reason for this is that they are innovators who create jobs and alleviate poverty (Adesua-Lincoln, 2012), and are inventors of new wealth, goods and services. They also have the capacity to transform society and economy at large (Cohoon et al. 2010), by moving people in the community from the position of not have to have. Achieving these is not just ordinary, but it has to be with possession of competencies. Entrepreneurs use their competencies to search, create and exploit business opportunities available within the environment.

Competency of the entrepreneurs is one of the significant determining factors for success, performance and growth or failure of business operation (Kiggundu, 2002; Brinckmann, 2008; Mitchelmore and Rowley, 2013). Furthermore, female Entrepreneurs mostly operate small-scaled type of businesses which requires the businesses to depend mainly on the competencies of the owner. Thus, understanding the nature of such competencies in the context of female Entrepreneurs is very important (Mitchelmore and Rowley, 2010; Mitchelmore et al. 2008).

However, females leading businesses in Nigeria like their counterpart in other parts of the world face numerous business challenges which range from competing with foreign-made products to bigger and smaller businesses owned by male entrepreneurs in their country. For them to remain in business despite these difficulties needs competencies that will ensure to present their goods and services to their customers at attractive and profitable prices with excellent quality. Meanwhile, some of the businesses that the women in Nigeria are involved in are: tailoring, poultry, spices, local soft drink (zobo, ginger), cosmetics, trading, 
food and beverages, aquaculture (fish farming, aquatic plants etc.), snacks, cane work, crop marketing, beat making, bags making, catering, bakery, production of liquid detergent, production of coconut oil, production of 'gari' and palm oil processing, making of rice flour and so forth.Therefore, the aims of this study are: 1) to examine relationship that exists between strategic competency and firm performance; 2) to examine relationship that exists between opportunity competency and firm performance; 3) to examine relationship that exists between organising competency and firm performance.

\section{METHODS}

The sample of this study comprised 200 women entrepreneurs. They are running various micro businesses in Kaduna state, Nigeria. Simple random sampling technique was adopted for this study. To obtain the 200 respondents, the process involved picking of pieces of paper in box without replacement, which contained the names of the women entrepreneurs, as provided by Small and Medium Enterprises Development Agency of Nigeria (SMEDAN) Kaduna state office. This process was conducted until 200 female Entrepreneurs were picked. Thus, the data were collected using questionnaires.

Survey instrument used to measure entrepreneurial competencies such as strategic, opportunity and relationship competencies was adopted from Man (2001) and Ahmad (2007). Each of the female entrepreneurs was requested to rate the items that best described the competencies they possessed. A five point Likert-scale was used. The ratings started from 1 strongly disagree to 5 strongly agree.

Furthermore, survey instrument used for measuring firm performance was adopted form Chandler and Hanks (1993). The rating was also based on five point Likert-scales, starting from 1 very dissatisfied to 5 very satisfied. This research framework was proposed for empirical investigation of the relationship between the constructs (Figure 1).

To gain credible performance by female Entrepreneurs in their business, acquiring and leveraging on their competencies are of great importance. Competencies enhance competitiveness of their firm in the market regarding cost reduction, brand loyalty, good recommendation by customers and reputation among consumers (López-Gamero et al. 2009). Thus, resources and capabilities possessed by the entrepreneurs will provide them the avenue to outperform their competitors and achieve great success in their business endeavours.

Competency as a term has long been used in most management literature. It can be divided into two: natural competence and unnatural competence. Meutia and Ismail (2012) stated that natural competence consists of characteristic, attitude, self-image and social role. Unnatural or learned competence is skills that are needed when a task is done, which is acquired through practical and theoretical learning. This includes skills, knowledge and experience. Therefore, entrepreneurial competencies are the underlying characteristics possessed by an individual which assist them to execute the tasks in a manner that is most befitting (Lazar and Paul, 2015).

Strategic competency is related to setting, evaluating and implementing the strategies for the whole firm (Man et al. 2002). Ahmad et al. (2010) articulated strategic competency as the ability of the entrepreneur to monitor progress toward strategic goals, prioritise task to agree with business objectives, identify longterm issues, threats or opportunities, current actions to be in line with strategic goals, match the outcome against strategic goals, redesign business to achieve long-termgoals adequately, determine strategic actions through weighing costs and benefits. It is also, the ability to setup long term strategic plan that relates to the vision of the organization and also develop strategies that will enable the achievement of the plan (Stonehouse and Pemberton, 2002).

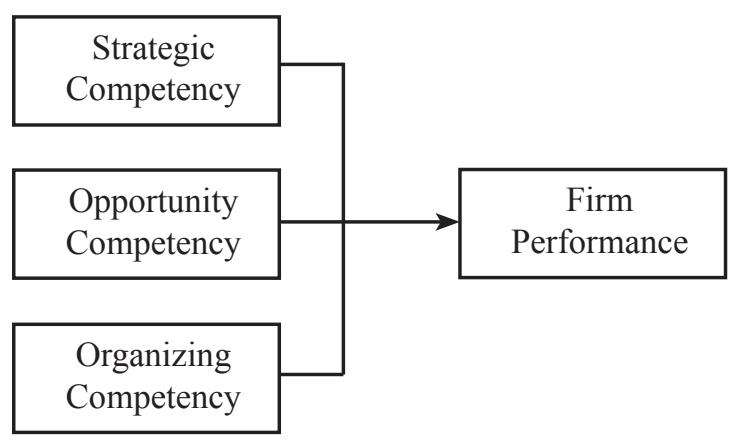

Figure 1. Research Framework 
One of the central functions of the entrepreneurs is to be able to identify and make the best use of business opportunities capable of stimulating the performance of the firm. Opportunity competency comprises the entrepreneurial activities in actively seeking new opportunities, spotting opportunities, and developing the opportunities (Seabela and Fatoki, 2014). HoyosRuperto et al. (2013) stated that the entrepreneurial and positive perception of numerous opportunities available in the marketplace is one of the important conditions that are crucial to the success of the firm. It indicates that female entrepreneurs that want accelerated growth for their business should take possession of this type of competency with deserved seriousness. If she does not take it, her business will not experience growth as expected.

Organizing competency is the capacity of the entrepreneur to direct, lead, delegate, encourage, plan and schedule work, develop the program and prepare the finances of the firm (Kaur and Bains, 2013). This competency is related to managerial competency (Umeze and Ohen, 2015). It involves managing both internal and external programs of the organization, for instance, promotion of firm's goods and services, proper financial management, logistics and management of human resources (Lans et al. 2011; Wickramaratne et al. 2014).

Furthermore, this competency also involves a process of breaking down the task into convenient obligations or duties, in which task will be grouped and qualified staff will be responsible for its execution as planned (UNESCO-Nigeria TVE, 2010). Thus, organizing competency will aid female Entrepreneurs in the efficient coordination of all resources of their firms for optimum utilization. By ensuring that right thing is performed at the right time by the right people.

In the field of strategic management, firm performance has been considered as one of the ultimate criterion variables (Aziz and Mahmood, 2011). It is a central issue in business activities. Therefore, achieving it demands adequate and diligent planning and commitment (Shehu and Mahmood, 2014). According to Oo (2013), firm performance could mean the success level of the business in the market within which it operates. Business Performance can also be referred to as the yardstick use to quantify results achieved by the firm for a particular period of time (Sucipto, Oktaviani, \& Rizal, 2015). Whatever the definition is adopted, as indicated by Trkman (2010), business performance evaluation is a critical issue. Hence, the performance enables monitoring of either success or failure of the organization. Meanwhile, issues such as customer brand loyalty, an increase in the volume of sales, customer satisfaction, growth in market shares and adequate return on investment are integral components of firm performance (Morgan, 2012).

In view of foregoing discussion and research framework in Figure 1, the following hypotheses were formulated:

H1: Strategic competency will be positively related to firm performance.

H2: Opportunity competency will be positively related to firm performance.

H3: Organising competency will be positively related to firm performance.

\section{RESULTS}

This section presents findings of this study. It used two software which comprised Statistical Package for social sciences (SPSS) and Partial Least Square(SmartPLS) version 3.0. SPSS was used for data entry and purification. SmartPLS was used for higher statistical analysis. In this study no case of missing data and extreme case of outlier was recorded.

\section{Measurement Model Evaluation}

The measurement model evaluation of this study was performed to determine the reliability of the items and construct validity. It is made-up of internal consistency reliability and constructs validity to establish item reliability and construct accuracy (Hair, Hult, Ringle, \&Sarstedt, 2014). PLS Algorithm graph for this research is presented in Figure 2.

\section{Reliability Analysis}

In the evaluation of internal consistency reliability, outer loadings and their respective indicator reliability are presented to portray Composite Reliability. This is because, composite reliability puts emphasis on individual item reliability which must be 0.5 (Hair et al. 2014). However, Hulland (1999) argued that indicator is said to be reliable if the value is 0.4 or above. The result of this study revealed that all indicators are reliable. Hence, the values were greater than 0.4 as 
recommended. Similarly, all composite reliability (CR) measurements are more than the cut-off values of 0.70 recommended by (Hair et al. 2014). This indicates that all the constructs are reliable as shown in Table 1.

Convergent validity and discriminant validity were evaluated to indicate construct validity while the construct validity was examined through the outer loadings and AVE; moreover, Discriminant validity was examined through Fornell-Larcker criterion.

Hair, Black, Babin, and Anderson (2010) argued that 0.6 or higher is the minimum outer loading coefficient in a measurement model. Hair et al. (2014) suggested 0.70 or higher as the minimum outer loading. Furthermore, Hair et al. (2014) suggested an AVE value of 0.50 or above shows that, on average, the variable explains more than half of the variance of its indicators. Table 1showed that, all the outer loadings are above 0.60 while the AVE has achieved 0.50 and above.

\section{Discriminant Validity}

It means that a variable is unique and captures phenomena not represented by other varying constructs in the model. The most popular method used in determining Discriminant validity of construct is Fornell-Larcker criterion. It indicates that square root of AVE of each variable is greater than the correlation for each construct. The figures in bold in Table 2 are all greater than each of the coefficients on which they have been placed. This indicates that a discriminant validity of constructs has been achieved (Hair et al. 2014). The results of discriminant validity are presented in Table 2.

\section{Structural Model Evaluation}

The paths of the relationship between the independent and dependent variable were computed in the structural model and bootstrap analysis was performed to evaluate the statistical significance of the path coefficient. The significance levels were set at $\mathrm{p}<.10 \mathrm{p}<.05$ and $\mathrm{p}$ $<.01$. The critical values are $1.65,1.96$ and 2.57 . The confidence levels are taking at $90 \%, 95 \%$ and $99 \%$ respectively. The 500 bootstrapping depicting coefficients for the paths regression effects are presented in Figure 3.

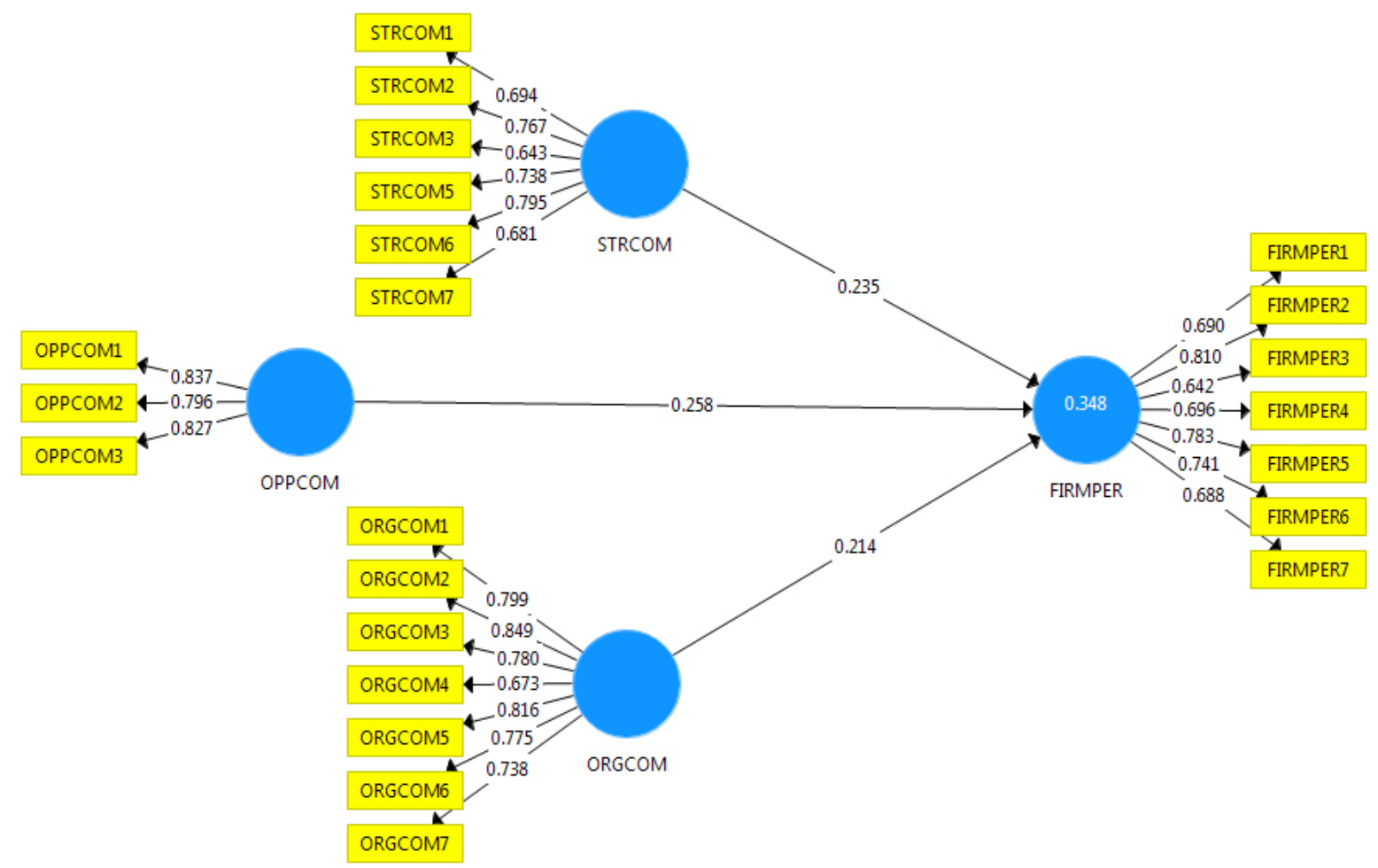

STRCOM = Strategic competency, OPPCOM = Opportunity competency, ORGCOM = Organising competency, FIRMPER $=$ Firm performance.

Figure 2. PLS Algorithm graph 
Table 1. Parameter estimates of the measurement model

\begin{tabular}{|c|c|c|c|c|c|}
\hline Latent variable & Manifest variable & Outer loadings & Indicator reliability & Composite reliability & $\begin{array}{c}\text { Average variance } \\
\text { extracted }\end{array}$ \\
\hline STRCOM & $\begin{array}{l}\text { STRCOM1 } \\
\text { STRCOM2 } \\
\text { STRCOM3 } \\
\text { STRCOM5 } \\
\text { STRCOM6 } \\
\text { STRCOM7 }\end{array}$ & $\begin{array}{l}0.694 \\
0.767 \\
0.643 \\
0.738 \\
0.795 \\
0.681\end{array}$ & $\begin{array}{l}0.482 \\
0.588 \\
0.414 \\
0.545 \\
0.632 \\
0.464\end{array}$ & 0.866 & 0.521 \\
\hline OPPCOM & $\begin{array}{l}\text { OPPCOM1 } \\
\text { OPPCOM2 } \\
\text { OPPCOM3 }\end{array}$ & $\begin{array}{l}0.837 \\
0.796 \\
0.827\end{array}$ & $\begin{array}{l}0.701 \\
0.634 \\
0.684\end{array}$ & 0.860 & 0.673 \\
\hline ORGCOM & $\begin{array}{l}\text { ORGCOM1 } \\
\text { ORGCOM2 } \\
\text { ORGCOM3 } \\
\text { ORGCOM4 } \\
\text { ORGCOM5 } \\
\text { ORGCOM6 } \\
\text { ORGCOM7 }\end{array}$ & $\begin{array}{l}0.799 \\
0.849 \\
0.780 \\
0.673 \\
0.816 \\
0.775 \\
0.738\end{array}$ & $\begin{array}{l}0.638 \\
0.721 \\
0.608 \\
0.453 \\
0.666 \\
0.601 \\
0.545\end{array}$ & 0.914 & 0.605 \\
\hline FIRMPER & $\begin{array}{l}\text { FIRMPER1 } \\
\text { FIRMPER2 } \\
\text { FIRMPER3 } \\
\text { FIRMPER4 } \\
\text { FIRMPER5 } \\
\text { FIRMPER6 } \\
\text { FIRMPER7 }\end{array}$ & $\begin{array}{l}0.690 \\
0.810 \\
0.642 \\
0.696 \\
0.783 \\
0.741 \\
0.688\end{array}$ & $\begin{array}{l}0.476 \\
0.656 \\
0.412 \\
0.484 \\
0.613 \\
0.549 \\
0.473\end{array}$ & 0.884 & 0.524 \\
\hline
\end{tabular}

Table 2. Discriminant validity of construct Fornell-Larcker criterion

\begin{tabular}{lcccc}
\hline & Firm performance & Opportunity competency & Organising competency & Strategic competency \\
\hline Firm performance & 0.724 & & & \\
Opportunity competency & 0.515 & 0.820 & 0.778 & 0.722 \\
Organising competency & 0.456 & 0.508 & 0.471 & 0.630 \\
Strategic competency & 0.498 & 0.41 & \\
\hline
\end{tabular}

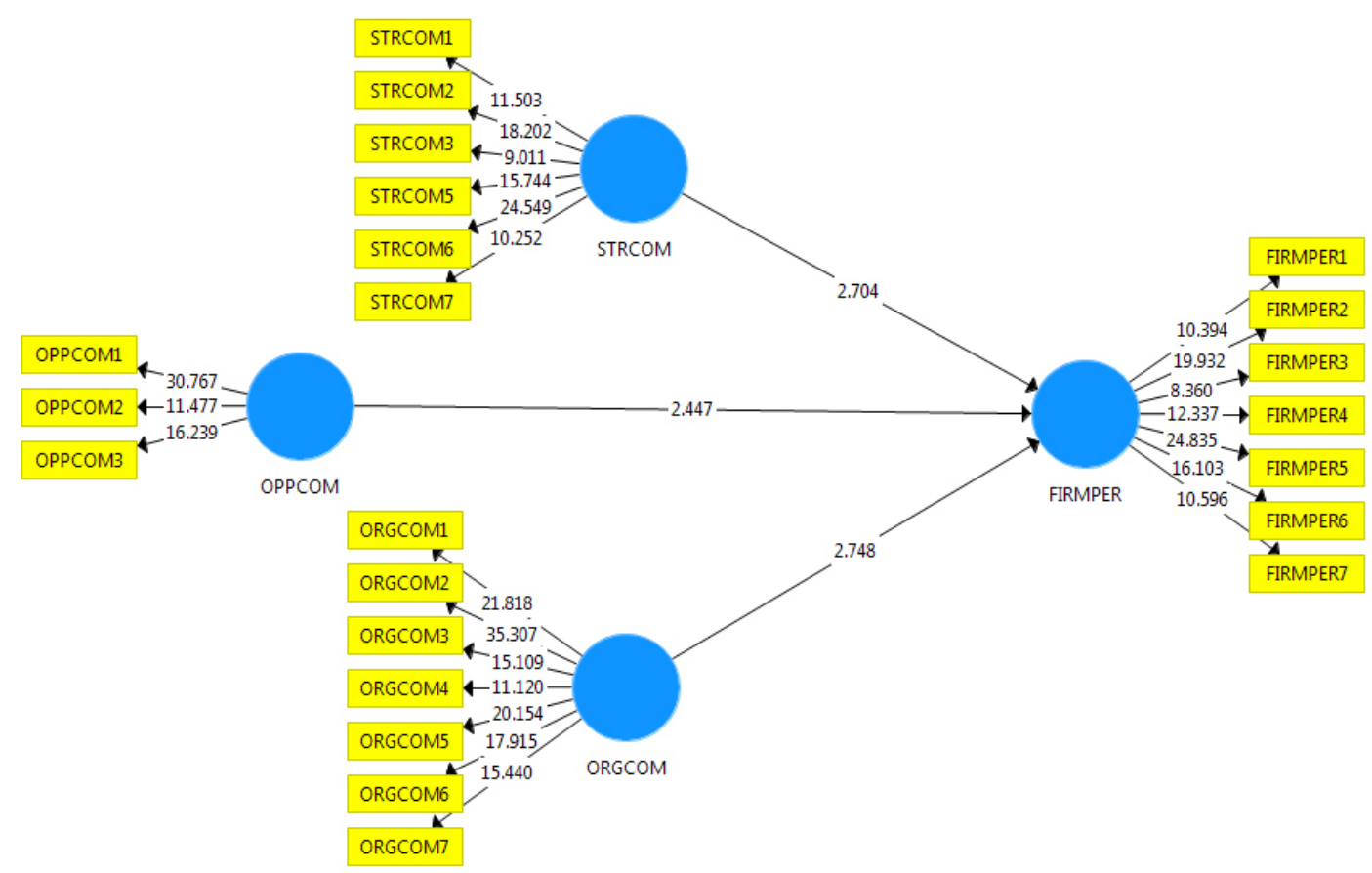

Figure 3. PLS 500 Bootstrap Graph 
From the regression results, all the three constructs of independent variable were positively related to firm performance which is the dependent variable. Strategic competency (STRCOM) as independent variable with $(\beta=0.235, \mathrm{t}=2.704, \mathrm{p}<0.01)$ has a direct positive effect on firm performance (FIRMPER). Opportunity competency (OPPCOM) as independent variable with $(\beta=0.258, \mathrm{t}=2.447, \mathrm{p}<0.05)$ has a direct positive effect on firm performance (FIRMPER). Similarly, organizing competency (ORGCOM) as independent variable with $(\beta=0.214, \mathrm{t}=2.748, \mathrm{p}<0.01)$ has a direct positive effect on firm performance (FIRMPER). Therefore, hypotheses $\mathrm{H} 1, \mathrm{H} 2$ and $\mathrm{H} 3$ of this study were all supported. Table 3 shows the statistical detail of parameter estimates of direct effect relationships for this study.

\section{Coefficient of Determination $\left(\mathrm{R}^{2}\right)$}

As a degree of model's predictive accuracy, $\mathrm{R}^{2}$ represents the exogenous constructs' combined effects on the endogenous construct. Scholarly researches consider $0.67,0.33$ and 0.19 as substantial, moderate and weak respectively (Chin, 1998). In this structural model, the three exogenous variables; strategic competency (STRCOM), opportunity competency (OPPCOM) and organizing competency (ORGCOM) explained $35 \%$ of the variance in firm performance (FIRMPER) as dependent variable. The Coefficient of Determination $\left(\mathrm{R}^{2}\right)$ for this study is considered moderate.

\section{Effect Size ( $\left.\mathbf{f}^{2}\right)$}

This is an evaluation of fundamental impact of exogenous variables on the endogenous variable when the former is omitted from the model. Chin (2010) stated that, in social science researches, $2 \%$ effect sizes are small but acceptable, 5-10\% moderate, while $11 \%$ and above are substantial. Paterson, Harms, Steel, and Credé (2016) stated that, based on the opinion of Cohen, lots of effects in the social sciences are mostly small, but acceptable. The effect size $\mathrm{f}^{2}$ was determined using this formula:

$$
\mathrm{f}^{2}=\left(\mathrm{R}^{2} \text { inclusive }-\mathrm{R}^{2} \text { exclusive }\right) / 1-\mathrm{R}^{2} \text { inclusive }
$$

where:

$$
\begin{aligned}
& \mathrm{R}^{2} \text { inclusive : } \begin{array}{l}
\text { Variance explained coefficient } \\
\text { when the variable is included in } \\
\text { the model }
\end{array} \\
& \mathrm{R}^{2} \text { exclusive : } \begin{array}{l}
\text { Variance explained coefficient } \\
\text { when the variable is excluded } \\
1
\end{array}
\end{aligned}
$$

The effect sizes as presented in Table 4 consist of STRCOM (0.048), OPPCOM (0.045) and ORGCOM (0.047). The result of the interaction between the independent variable and dependent variable indicated that the effects of strategy, opportunity and organizing competencies on firm performance are small. Therefore, all the three independent variable of this study have effect on dependent variable.

\section{Predictive Relevance $\left(\mathrm{Q}^{2}\right)$}

To obtain predictive relevance of exogenous variables on the endogenous variable, Cross-Validated Redundancy is used. Every dth data point in the construct's indicators is omitted and evaluates the parameters with the remaining data points. The omission distance is usually chosen between 5 and 10, and for this study, figure of 7 was chosen. Hair et al. (2014) stated that values greater than zero show that exogenous constructs have predictive relevance for the endogenous construct. Table 5 presents the result of predictive relevance for this study. The table showed that all independent variables have predictive relevance on dependent variable. Hence, all $\mathrm{Q}^{2}$ have values greater than 0 .

The result of this study proved that entrepreneurial competency plays a significant role in successes recorded by all business organizations. Female Entrepreneurs in Nigeria with good entrepreneurial competencies seem to be in a superior position than their competitors with lower level of competencies. Their competency enables them to triumph in the market despite stiff competition in their respective business environment.

Table 3. Parameter estimates of direct effect relationships

\begin{tabular}{lccccc}
\hline Hypotheses & \multicolumn{1}{c}{ Path } & B & SE & t value & Decision \\
\hline H1 & STRCOM $\rightarrow$ FIRMPER & 0.235 & 0.087 & $2.704 * * *$ & Supported \\
H2 & OPPCOM $\rightarrow$ FIRMPER & 0.258 & 0.105 & $2.447 * *$ & Supported \\
H3 & ORGCOM $\rightarrow$ FIRMPER & 0.214 & 0.078 & $2.748^{* * *}$ & Supported \\
\hline
\end{tabular}

***significant at $\mathrm{p}<0.01, * *$ significant at $\mathrm{p}<0.05, *$ significant at $\mathrm{p}<0.10$, All hypotheses are one tailed. 
Table 4. Effect Sizes $\left(\mathrm{f}^{2}\right)$

\begin{tabular}{lllll}
\hline \multicolumn{1}{c}{ Variable } & \multicolumn{1}{c}{$\mathrm{R}^{2}$ inclusive } & $\mathrm{R}^{2}$ exclusive & Effect $\left(\mathrm{f}^{2}\right)$ & Size \\
\hline Strategic competency (STRCOM) & 0.348 & 0.316 & 0.048 & Small \\
Opportunity competency (OPPCOM) & 0.348 & 0.318 & 0.045 & Small \\
Organising competency (ORGCOM) & 0.348 & 0.317 & 0.047 & Small \\
\hline
\end{tabular}

Table 5. Predictive relevance $\left(\mathrm{Q}^{2}\right)$

\begin{tabular}{cc}
\hline Number of Rounds & Endogenous variable Firm Performance \\
\hline Case 1 & 0.187 \\
Case 2 & 0.186 \\
Case 3 & 0.162 \\
Case 4 & 0.119 \\
Case 5 & 0.129 \\
Case 6 & 0.160 \\
Case 7 & 0.124 \\
\hline
\end{tabular}

All cases were obtained by 1 - Sum of Square Error (SSE)/Sum of Square Observation (SSO) using blindfolding technique.

In one hand, the result obtained in this study is in agreement with the result of the study conducted by some of the previous researchers. On the other hand it did not concur with others. For instance the study conducted by Man, Lau, \& Snape, (2008) indicated that there is a direct relationship between strategic competency and business performance especially when investment efficiency is used to evaluate the performance of the firm. Study conducted by conducted by Man and Lau (2005) revealed that business entrepreneurs Hong Kong ranked low strategic competency. They claimed that scope of their business is low; therefore, they do not need strategic competency.

However, the results of this study proved that it is of utmost importance for business owners to have long term and comprehensive plan for their business. Plans and its resultant execution cannot be achieved without possession of competencies. Hence, strategic competency possessed by female Entrepreneurs in Nigeria enables them to take their business as a going concern concept, not a business set up to die within a short period of time.

Similarly, opportunity competency is considered as one of the most distinctive competencies for the business owners. Business opportunities are those needs and want of the customers yet to be satisfied. It is not every business opportunity that is profitable. It has to be evaluated before investing in it. The result obtained in this study shows that female Entrepreneurs in Nigeria got the ability to actively search and make fortuitous discovery of business opportunities. They understood that discovery of profitable business opportunities will provide avenue for their business to achieve success and sustain their competitive advantage. Thus, opportunity competency encouraged female Entrepreneurs in Nigeria to take considerable risks which eventually turn out to be a profitable business venture.

Furthermore, the result of this study proved that organizing competency has the capacity to improve the performance of a business firm. This is similar to study conducted by Ahmad (2007) who indicated that those entrepreneurs in Australia and Malaysia spend most of their time in planning and organizing human and other physical resources of their firms. They understood that without organizing these resources, business success will be far away from them. Female Entrepreneurs in Nigeria also took their time to ensure that they organise their resources, delegate task effectively and motivate one or few staff working with them. Through this, performance of their firm is enhanced. Hence, there is no magic for success; however, by efficient coordination of the little resource in the disposal of entrepreneurs, successes can be achieved.

\section{Managerial Implication}

In any profit making organization, the owner of such business is considered as the most vital element. In this regard, entrepreneurs are the ones responsible for the provision of all necessary resources needed for day to day running of the business to achieve success. They 
also have in their mind where they want the business to be in the future, which will be made known to their employees and subordinates in other to work as a team. Therefore, it is important for female Entrepreneurs in Nigeria to effectively cope with challenges faced because of owning a business. Acquiring and implementing competencies become very vital. In addition to this, it will warrant their rapid penetration of the market at abated cost and higher profitability.

\section{CONCLUSIONS AND RECOMMENDATIONS}

\section{Conclusions}

The result obtained from this study has proved the link between competencies of female Entrepreneurs in Nigeria and their business performance. This agrees with at the same time in disagreement with some of the previous studies. For instance, the result obtained in this study concurred with the studies conducted by Man et al. (2008), Ahmad, et al. 2010 and Ahmad (2007), that strategy, opportunity and organizing competencies are positively related to firm performance. On the other hand, the result of this study disagrees with the studies conducted by Man and Lau (2005), Lopa and Bose (2014), whereby their studies revealed that no significant relationship between entrepreneurial competencies under review with firm performance.

To this end, government of Nigeria and other stakeholders need to focus their attention on issues that must do with entrepreneurial development of women such as training and development, provision of loan facilities at a low cost among others. Hence, Nigeria is one of the countries blessed with women population. They get the potentiality to contribute to economic development of Nigeria via job creation and alleviation of poverty.

\section{Recommendations}

It is; therefore, recommended that future research needs to focus on female Entrepreneurs in informal sector; hence, this study focused only on female Entrepreneurs in formal sector that engage in businesses in service, trade, manufacturing and agricultural sector. Qualitative research can also be conducted for more understanding of competencies of female Entrepreneurs in Nigeria.

\section{REFERENCES}

Adesua-Lincoln, A. 2012. Nature of leadership practices of Nigerian female entrepreneurs. International Journal of Business and Social Science 3(10): $50-59$.

Ahmad NH. 2007. A cross-cultural study of entrepreneurial competencies and entrepreneurial success in SMEs in Australia and Malaysia. [thesis]. Australia: University of Adelaide Australia.

Ahmad NH, Ramayah T, Wilson C, Kummerow L. 2010. Is entrepreneurial competency and business success relationship contingent upon business environment? A study of Malaysian SMEs. International Journal of Entrepreneurial Behavior \& Research 16(3): 182-203.

Aziz S A, Mahmood R. 2011. The relationship between business model and performance of manufacturing small and medium enterprises in Malaysia. African Journal of Business Management 5(22): 8918-8932. DOI: 10.5897/ AJBM11.474.

Brinckmann J. 2008. Competence of Top Management Teams and Success of New Technology-Based Firms. Berlin: Springers.

Chandler GN, Hanks SH. 1993. Measuring the performance of emerging businesses: avalidation study. Journal of Business Venturing 8(5): 391408.

Chin WW. 1998. The partial least squares approach to structural equation modeling. Modern methods for business research 295(2): 295-336.

Chin WW. 2010. How to Write Up and Report PLS Analyses Handbook of Partial Least Squares. Berlin: Springer.

Cohoon, J. M., V. Wadhwa and L. Mitchell. 2010. Are Successful Women Entrepreneurs Different From Men? SSRN 2010: 1-16. http://dx.doi. org/10.2139/ssrn.1604653

Hair JF, Black WC, Babin BJ, Anderson RE. 2010. Multivariate Data Analysis. New Jersey:Upper Saddle River.

Hair JF, Hult GTM, Ringle CM, Sarstedt M. 2014. A Premier on Partial Least Squares Structural Equation Modelling (PLS-SEM). United States of America: Sage.

Hoyos-Ruperto MD, Romaguera JM, Carlsson B, Lyytinen K. 2013. Networking: A critical success factor for entrepreneurship. American Journal of Management 13(2): 55-72. 
Hulland J. 1999. Use of partial least squares (PLS) in strategic management research: A review of four recent studies. Strategic Management Journal 20(2): 195-204.

Kaur H, Bains A. 2013. Understanding the concept of entrepreneur competency. Journal of Business Management \& Social Sciences Research 2(11): 31-33.

Kiggundu MN. 2002. Entrepreneurs and entrepreneurship in Africa: What is known and what needs to be done. Journal of developmental entrepreneurship 7(3): 239.

Lans T, Verstegen J, Mulder M. 2011. Analysing, pursuing and networking: Towards a validated three-factor framework for entrepreneurial competence from a small firm perspective. International Small Business Journal 29(6): 695-713.

Lazar N, Paul G. 2015. Entrepreneurial competencies in a business enterprise-Anoverview. International Journal of Scientific Research 4(1): 226-227.

López-Gamero, MD, Molina-Azorín JF, ClaverCortes E. 2009. The whole relationship between environmental variables and firm performance: Competitive advantage and firm resources as mediator variables. Journal of environmental management 90(10): 3110-3121.

Man TW, Lau T. 2005. The context of entrepreneurship in Hong Kong: An investigation through the patterns of entrepreneurial competencies in contrasting industrial environments. Journal of Small Business and Enterprise Development 12(4): 464-481.

Man TW, Lau T, Chan K. 2002. The competitiveness of small and medium enterprises: A conceptualization with focus on entrepreneurial competencies. Journal of Business Venturing 17(2): 123-142.

Man TW, Lau T, Snape E. 2008. Entrepreneurial competencies and the performance of small and medium enterprises: an investigation through a framework of competitiveness. Journal of Small Business \& Entrepreneurship 21(3): 257-276.

Man WT. 2001. Entrepreneurial competencies and the performance of small and medium enterprises in the Hong Kong services sector [thesis]. Hongkong: the Hong Kong Polytechnic University.

Meutia, Ismail T. 2012. The development of entrepreneurial social competence and business network to improve competitive advantage and business performance of small medium sized enterprises: a case study of batik industry in Indonesia. Procedia-Social and Behavioral Sciences 65: 46-51.

Mitchelmore S, Rowley J. 2010. Entrepreneurial competencies: a literature review and development agenda. International Journal of Entrepreneurial Behavior \& Research 16(2): 92-111.

Mitchelmore S, Rowley J. 2013. Entrepreneurial competencies of women entrepreneurs pursuing business growth. Journal of Small Business and Enterprise Development 20(1): 125-142.

Mitchelmore S, Rowley J, Shiu E. 2008. Competencies associated with growth of women-led SMEs. Journal of Small Business and Enterprise Development 21(4): 588-601.

Morgan NA. 2012. Marketingand business performance. Journal of the Academy of Marketing Science 40(1): 102-119.

Oo HM. 2013. Determinants of SMEs' performance: the case of Kyaing Tong, Eastern Shan State, Myanmar. AU-GSB e-JOURNAL 6(2):54-67.

Paterson TA, Harms P, Steel P, Credé M. 2016. An assessment of the magnitude of effect sizes evidence from 30 years of meta-analysis in management. Journal of Leadership \& Organizational Studies 23(1): 66-81.

Seabela M, Fatoki O. 2014. The entrepreneurial competencies of non-business university students in South Africa. International Journal of Educational Research 6(3): 375-381.

Shehu AM, Mahmood R. 2014. The relationship between market orientation and business performance of Nigerian SMEs: The role of organizational culture. International Journal of Business and Social Science 9(1): 159-168.

Stonehouse G, Pemberton J. 2002. Strategic planning in SMEs-some empirical findings. Management Decision 40(9): 853-861.

Sucipto E, Oktaviani R, Rizal R. 2015. The effects of partnership and entrepreneurship toward business performance of oyster mushroom (pleurotusostreatus). Indonesian Journal of Business and Entrepreneurship 1(1), 32-41.

Trkman P. 2010. The critical success factors of business process management. International journal of information management 30(2): 125-134.

Umeze GE, Ohen SB. 2015. Marketing Mix Strategies and Entrepreneurial Competence: Evidence from Micro Restaurants in Calabar Metropolis, Cross 
P-ISSN: 2407-5434 E-ISSN: 2407-7321

Accredited by Ministry of RTHE Number 32a/E/KPT/2017
River State, Nigeria. Paper presented at the 2015

Conference, August 9-14, 2015, Milan, Italy.

UNESCO-Nigeria TVE. 2010. Instructional/Teaching

Material. Nigeria: National Board for Technical Education.
Wickramaratne A, Kiminami A, Yagi H. 2014. Entrepreneurialcompetenciesandentrepreneurial orientation of tea manufacturing firms in Sri Lanka. Asian Social Science 10(18): 50-63. http://dx.doi.org/10.5539/ass.v10n18p50 